\title{
SUCROSE PULSING AND COLD STORAGE ON POST-STORAGE ATTRIBUTES OF CUT LILY FLOWERS IN DALAT, VIETNAM
}

\author{
Le Nhu Bich ${ }^{a^{*}}$, Nguyen Thi Hong Nhung ${ }^{\mathrm{b}}$ \\ ${ }^{a}$ The Faculty of Agriculture and Forestry, Dalat University, Lamdong, Vietnam \\ ${ }^{b}$ The Postgraduate Student of the Faculty of Applied Biology, Dalat University, Lamdong, Vietnam \\ *Corresponding author: Email: bichln@dlu.edu.vn
}

\author{
Article history \\ Received: July $22^{\text {nd }} 2019$ \\ Received in revised form $\left(1^{\text {st }}\right)$ : August $26^{\text {th }}, 2019 \mid$ Recieved in revised form $\left(2^{\text {nd }}\right)$ : September $16^{\text {th }}, 2019$ \\ Accepted: December 17 $7^{\text {th }}, 2019$
}

\begin{abstract}
The effects of sucrose pulsing, cold storage methods (dry and wet), and cold storage duration (one and two weeks) on the post-storage attributes of cut lilies in Dalat were studied. After harvest, the lilies were treated with sucrose pulsing solutions consisting of three concentrations of sucrose $(0,50$, and $100 \mathrm{~g} / \mathrm{L})$ in combination with $0.2 \mathrm{mM}$ silver thiosulphate (STS) and water as control for $24 \mathrm{~h}$ at room temperature, then placed in wet and dry cold storage at $2.5{ }^{\circ} \mathrm{C}$ for one and two weeks. After each period of cold storage, the cut lilies were placed in water to evaluate the vase life, the time of bud opening, the bud opening rate, and water uptake. The results showed that when cut lilies were treated with $50 \mathrm{~g} / \mathrm{L}$ sucrose in combination with STS $0.2 \mathrm{mM}$ and one-week cold storage, the vase life increased to 16.8 days with better color, the time of bud opening slowed down to 5.8 days, buds fully opened (100\%), and the water uptake remained constant at $91.5 \mathrm{ml}$.
\end{abstract}

Keywords: Cold storage; Lily; Pulsing treatment; Vase life.

DOI: http://dx.doi.org/10.37569/DalatUniversity.10.2.575(2020)

Article type: (peer-reviewed) Full-length research article

Copyright $\odot 2020$ The author(s).

Licensing: This article is licensed under a CC BY-NC 4.0 


\title{
TIỀN XỦ̉ LÝ SUCROSE VÀ BẢO QUẢN LẠNH LÊN \\ CÁC THUQ̣̂C TÍNH CỦA HOA LILY CẮT CÀNH SAU BẢO QUẢN TẠI THÀNH PHỐ ĐÀ LẠT, VIẸT NAM
}

\author{
Lê Như Bích ${ }^{\mathrm{a}^{*}}$, Nguyễn Thị Hồng Nhung ${ }^{\mathrm{b}}$ \\ ${ }^{a}$ Khoa Nông Lâm, Trường Đại học Đà Lạt, Lâm Đồng, Việt Nam \\ ${ }^{b}$ Hoc viên Cao họ ngành Sinh học Thực nghiệm, Truờng Đại học Đà Lạt, Lâm Đồng, Việt Nam \\ "Tác giả liên hệ: Email: bichln@dlu.edu.vn \\ Lịch sử bài báo \\ Nhận ngày 22 tháng 7 năm 2019 \\ Chỉnh sửa lần 01 ngày 26 tháng 8 năm 2019 | Chỉnh sửa lần 02 ngày 16 tháng 9 năm 2019 \\ Chấp nhận đăng ngày 17 tháng 12 năm 2019
}

\section{Tóm tắt}

Ảnh hưởng của việc tiền xử lý đuờng và bảo quản lên tuổi thọ và đặc điểm của hoa lily cắt cành ở thành phố Đà Lạt được nghiên cứu. Sau khi thu hoạch, hoa lily được xủ̉ lý bằng dung dịch đường sucrose ở ba nồng độ $(0,50$, và $100 \mathrm{~g} / \mathrm{L})$ kết hợp với $0.2 \mathrm{mM} S T S$ và xủ lý với nuớc (đối chứng) trong $24 \mathrm{~h}$ ở nhiệt độ phòng $\left(23^{\circ} \mathrm{C}\right)$, sau đó bảo quản lạnh vớt và lạnh ở nhiệt độ $2.5^{\circ} \mathrm{C}$. Sau một và hai tuần bảo quản lạnh, hoa lily được cắm trong nước để theo dõi thời gian cắm, thờ gian bắt đầu nở hoa, tỷ lệ nở, và sụ hấp thu nuớc. Kết quả cho thấy khi hoa lily được tiền xử lý với dung dịch sucrose $50 \mathrm{~g} / \mathrm{L}$, STS $0.2 \mathrm{mM}$ và bảo quản lạnh trong một tuần thì có thời gian cắm tăng (16.8 ngày) với màu sắc nở đẹp hơn, thời gian nở chậm hơn (5.8 ngày), các nụ hoa nở hoàn toàn (100\%), và duy trì sự hấp thụ nước (91.5 ml).

Từ khóa: Bảo quản lạnh; Hoa lily; Thời gian cắm; Tiền xử lý.

DOI: http://dx.doi.org/10.37569/DalatUniversity.10.2.575(2020)

Loại bài báo: Bài báo nghiên cứu gốc có bình duyệt

Bản quyền @ 2020 (Các) Tác giả.

Cấp phép: Bài báo này được cấp phép theo CC BY-NC 4.0 


\section{INTRODUCTION}

In Vietnam, like many other developing countries, the supply of cut flowers is very seasonal, while the lack of pre-treatment, refrigeration, and poor packaging leads to poor product quality and short vase life (Bich \& Batt, 2011). Lily (Lillium) is the high economic value flower in Vietnam (Dang et al., 2016). Its vase life is an important poststorage attribute. The short vase life of lilies may be one of the most important reasons for the inability of florists to develop a suitable market (Nemati, Tehranifar, Esfandiari, \& Rezaei, 2013). The main symptoms that shorten the vase life are abscission of buds, lack of bud opening, petal wilting, and leaf yellowing due to the sensitivity of cut lilies to ethylene. Cold storage of cut flowers during storage or shipment reduces the metabolism in the tissue, retards the respiration, transpiration, and multiplication of bacteria and fungi, and reduces ethylene production and action. Dry and wet storage methods are commonly used. In dry storage cut flowers are placed in a package and arranged in a carton. In wet storage cut flowers are held in a chemical solution (Rudnicki, Nowak, \& Goszczynska, 1991). The cold storage temperature of cut lilies is about $2.5^{\circ} \mathrm{C}$ (Prisa, Burchi, \& van Doorn, 2013). However, a cold storage period often drastically increases the number of floral buds that fail to open, hastens tepal wilting, induces or increases leaf yellowing, and promotes bud abscission. Some degree of cold-storage stress is typically imposed on lilies. As in other species, the vase life of lilies depends on the cultivated varieties, as well as the duration of the handling and shipping (van Doorn \& Han, 2011). Cold storage increases the sensitivity of flower buds to ethylene given after the cold period (Miller, 2014).

Many studies have shown that chemical treatment before cold storage (known as pulsing) to prevent infections and inhibit ethylene production and/or metabolism results in a prolonged storage and improved post storage vase life of cut flowers (Madhavi, 2007; Rudnicki et al., 1991; Song, Ko, Shin, Kwon, \& Lee, 1995; Waithaka, Reid, \& Dodge, 2001). Pulsing solutions for lilies are often composed of a mixture of chemicals, such as carbohydrates, plant growth regulators, ethylene inhibitors, biocides, and acidifiers, which may minimise the risk of physiological disorders that occur in cut flowers after harvest and cold storage, such as leaf chlorosis and blackening (Eason, 2002; Kim, Lee, $\&$ Suh, 2005). STS is used as a pretreatment to eliminate the effects of exogenous ethylene on cut flowers (Prisa et al., 2013; Waithaka et al., 2001). Sucrose is the major source of carbon for petal growth and the energy supply for cut flowers (Han, 2003). Cevallos and Reid (2001) studied the effect of dry and wet storage at different temperatures on the vase life of tulips, daffodils, irises, carnations, roses, and daisies. Their results showed that the vase life after wet storage at temperatures of $12.5^{\circ} \mathrm{C}$ and greater was significantly higher than the vase life after dry storage at those temperatures for all the flowers studied. Irises and carnations only survived storage at $15{ }^{\circ} \mathrm{C}$ and $20^{\circ} \mathrm{C}$ when stored in water. Han (2003) assessed the role of sugar in the vase solution of an oriental lily, 'Stargazer'. The addition of $2 \%$ sugar into the vase solution affected neither the longevity nor the size of the flowers, but significantly enhanced petal color. According to Nemati et al. (2013), the application of solutions containing nano-silver particles is recommended to improve postharvest of $L$. orientalis 'Bouquet'. 
Specific postharvest data are lacking for cut flowers, and therefore farmers, traders, and retailers face problems to market and distribute high quality flowers to consumers (Rudnicki et al., 1991). Inadequate knowledge on proper preharvest and postharvest handling methods among the majority of farmers and sellers contributed largely to considerable postharvest losses in cut flowers (Weeraratne, Daundasekera, \& Wijesundara, 2012). Miller (2014) asserted that there is a need to determine the effects of sucrose pulsing in cut stems and the effects of storage temperature and duration on a range of lily cultivars in different hybrid groups. Since then, an attempt was made to find out the effects of sucrose pulsing treatment combined with STS and the two cold storage methods (dry and wet) at $2.5^{\circ} \mathrm{C}$ and two storage periods (one and two weeks) on the poststorage attributes of cut lilies in Dalat. This is in accordance with the aim of Dalat farmers and wholesalers to extend the vase life of the flowers after the expected time or storage of flowers in stock or transport.

\section{MATERIALS AND METHODS}

\subsection{Plant materials}

This experiment was conducted at the Laboratory of Postharvest Technology, Dalat University, Lamdong, Vietnam. Three-month-old stems of hybrid lilies (Lilium longiflorum) were harvested on a morning in September. Lilies were cut when the first floral bud reached the earliest possible stage of maturity (a partly-colored stage on the outlet tepals), then were delivered to the laboratory and immediately prepared for the experiment.

\subsection{Pulsing solutions and cold storage treatment}

Stems were recut to $60 \mathrm{~cm}$ and the lowermost leaves were removed. Five flower buds were left on each stem, six replicate stems. Upon arrival in the lab, stems were held in water (control) or in pulsing solutions containing $0 \mathrm{~g} / \mathrm{L}, 50 \mathrm{~g} / \mathrm{L}$, and $100 \mathrm{~g} / \mathrm{L}$ sucrose at an ambient temperature of $23^{\circ} \mathrm{C}$ for 24 hours, and STS at $0.2 \mathrm{mM}$ was added in all pulsing solutions as a base solution. After pulsing, the stems were then placed in a cold room with an average temperature of $2.5^{\circ} \mathrm{C}$ (Prisa et al., 2013) (range from $1.9{ }^{\circ} \mathrm{C}$ to $2.4{ }^{\circ} \mathrm{C}$ ) for a period of one or two weeks. During cold storage, the stems for wet storage were placed in the water treatment and sucrose treatments in separate buckets; The remains were wrapped in plastic sleeves and kept in a cardboard box for dry cold storage. At the end of each one- or two-week period, lily stems were recut and placed in a vase containing water at room temperature to complete vase life.

\subsection{Parameter analysis}

Observations were made daily, at the same time of the day. Vase life of each stem was based on the time after one or two weeks of storage until it became fully chlorotic. Vase life was terminated when greater than $50 \%$ of the flowers were fading and wilting. The ratio of bud opening was calculated by dividing the number of opened buds with the total number of buds per stem during the vase life trial (Eason, 2002; Kim et al., 2005). The time of bud opening is when the first bud on a stem opened (Prisa et al., 2013). Water 
uptake was measured every three days as the holding solution volume decreased in the vases containing flowers (Hajizadeh, Farokhzad, \& Chelan, 2012).

\subsection{Statistical analysis}

Data analysis was performed using the General Linear Model procedure (Ho, 2006) in SPSS (Statistical Package for the Social Sciences) software and data comparisons were performed according to Duncan's test $(p \leq 0.05)$.

\section{RESULTS AND DISCUSSION}

\subsection{Postharvest characteristics of cut lilies}

The vase life of cut lilies and the bud opening day were found to be significantly influenced by the pulsing treatments $(\mathrm{A})$ and cold storage duration $(\mathrm{C})(p<0.001)$. Data further revealed that cold storage methods (B) (dry and wet) did not have any significant effect on post-storage attributes of cut lilies. Statistical analysis performed on post-storage attributes also showed no interaction between solution pulsing and cold storage methods and duration $\mathrm{A}^{*} \mathrm{~B}, \mathrm{~A}^{*} \mathrm{C}$ (except the bud opening day), $\mathrm{B}^{*} \mathrm{C}$, and $\mathrm{A}^{*} \mathrm{~B} * \mathrm{C}(p<0.05)$; Therefore, they were independently analysed using an ANOVA (analysis of variance) (Table 1).

Table 1. Effects of sucrose pulsing, cold storage methods and duration on the postharvest characteristics of cut lilies

\begin{tabular}{|c|c|c|c|c|c|}
\hline $\begin{array}{l}\text { Pulsing treatment } \\
\text { (A) }\end{array}$ & $\begin{array}{l}\text { Cold storage } \\
\text { method (B) }\end{array}$ & $\begin{array}{l}\text { Cold storage } \\
\text { duration (week) (C) }\end{array}$ & $\begin{array}{l}\text { Vase life } \\
\text { (day) }\end{array}$ & $\begin{array}{l}\text { Time to bud } \\
\text { opening (day) }\end{array}$ & $\begin{array}{l}\text { Rate of bud } \\
\text { opening (\%) }\end{array}$ \\
\hline \multirow{7}{*}{ Water } & \multirow{3}{*}{ Dry } & 1 & $14.8 \mathrm{bcd}$ & $5.3 \mathrm{ab}$ & $94.4 \mathrm{a}$ \\
\hline & & & & & \\
\hline & & 2 & $13.7 \mathrm{~cd}$ & $4.5 \mathrm{abcd}$ & $97.2 \mathrm{a}$ \\
\hline & & & & & \\
\hline & \multirow{3}{*}{ Wet } & 1 & $14.2 \mathrm{~cd}$ & $4.8 \mathrm{abc}$ & $93.1 \mathrm{a}$ \\
\hline & & & & & \\
\hline & & 2 & $13.3 \mathrm{~d}$ & $5.3 \mathrm{ab}$ & $91.7 \mathrm{a}$ \\
\hline \multirow{7}{*}{$0 \mathrm{~g} / \mathrm{L}+\mathrm{STS}$} & \multirow{3}{*}{ Dry } & 1 & $16.7 \mathrm{a}$ & $5.7 \mathrm{ab}$ & $91.7 \mathrm{a}$ \\
\hline & & & & & \\
\hline & & 2 & $13.7 \mathrm{~cd}$ & $3.2 \mathrm{~d}$ & $96.7 \mathrm{a}$ \\
\hline & \multirow{4}{*}{ Wet } & & & & \\
\hline & & 1 & $15.5 \mathrm{abc}$ & $5.5 \mathrm{ab}$ & $100.0 \mathrm{a}$ \\
\hline & & & & & \\
\hline & & 2 & $13.8 \mathrm{~cd}$ & $3.8 \mathrm{~cd}$ & $96.7 \mathrm{a}$ \\
\hline
\end{tabular}

Note: Mean value has the same characters that are not significant with $p<0.050, \mathrm{~ns}, * *, * * *$ non-significance or significance at $p \leq 0.050$ or 0.0010 , respectively. 
Table 1. Effects of sucrose pulsing, cold storage methods, and duration on the postharvest characteristics of cut lilies (cont.)

\begin{tabular}{|c|c|c|c|c|c|}
\hline $\begin{array}{l}\text { Pulsing treatment } \\
\text { (A) }\end{array}$ & $\begin{array}{l}\text { Cold storage } \\
\text { method (B) }\end{array}$ & $\begin{array}{l}\text { Cold storage } \\
\text { duration (week) (C) }\end{array}$ & $\begin{array}{l}\text { Vase life } \\
\text { (day) }\end{array}$ & $\begin{array}{l}\text { Time to bud } \\
\text { opening (day) }\end{array}$ & $\begin{array}{l}\text { Rate of bud } \\
\text { opening }(\%)\end{array}$ \\
\hline \multirow{6}{*}{$50 \mathrm{~g} / \mathrm{L}+\mathrm{STS}$} & & 1 & $16.8 \mathrm{a}$ & $5.8 \mathrm{ab}$ & $100.0 \mathrm{a}$ \\
\hline & Dry & & & & \\
\hline & & 2 & $14.5 \mathrm{bcd}$ & $5.0 \mathrm{abc}$ & $95.8 \mathrm{a}$ \\
\hline & & 1 & $16.2 \mathrm{ab}$ & $6.0 \mathrm{a}$ & $93.3 \mathrm{a}$ \\
\hline & Wet & & & & \\
\hline & & 2 & $15.2 \mathrm{abcd}$ & $4.7 \mathrm{abc}$ & $92.5 \mathrm{a}$ \\
\hline \multirow{6}{*}{$100 \mathrm{~g} / \mathrm{L}+\mathrm{STS}$} & & 1 & $15.3 \mathrm{abc}$ & $4.8 \mathrm{abc}$ & $100.0 \mathrm{a}$ \\
\hline & Dry & & & & \\
\hline & & 2 & $14.2 \mathrm{~cd}$ & $4.3 \mathrm{bcd}$ & $100.0 \mathrm{a}$ \\
\hline & & 1 & $14.5 \mathrm{bcd}$ & $5.5 \mathrm{ab}$ & $100.0 \mathrm{a}$ \\
\hline & Wet & & & & \\
\hline & & 2 & $14.5 \mathrm{bcd}$ & $3.8 \mathrm{~cd}$ & $93.8 \mathrm{a}$ \\
\hline A & & & $* * *$ & $* *$ & $\mathrm{~ns}$ \\
\hline B & & & ns & ns & ns \\
\hline $\mathrm{C}$ & & & $* * *$ & $* * *$ & $\mathrm{~ns}$ \\
\hline $\mathrm{A} * \mathrm{~B}$ & & & ns & ns & ns \\
\hline $\mathrm{A} * \mathrm{C}$ & & & ns & $* *$ & $\mathrm{~ns}$ \\
\hline $\mathrm{B} * \mathrm{C}$ & & & ns & ns & ns \\
\hline $\mathrm{A} * \mathrm{~B} * \mathrm{C}$ & & & ns & ns & ns \\
\hline
\end{tabular}

Note: Mean value has the same characters that are not significant with $p<0.050, \mathrm{~ns}, * *, * * *$ nonsignificance or significance at $p \leq 0.050$ or 0.0010 , respectively.

The lily stems kept their quality, showing more than 10 days of vase life in all the evaluated treatments, for which the highest vase life was 16.8 days and the lowest was 13.3 days (Table 1). Vase life was significantly longer (up to one to two days) when cut lilies were pulsed with $0.2 \mathrm{mM}$ STS and $50 \mathrm{~g} / \mathrm{L}$ sucrose compared to water (Table 1). No differences in the lily vase life were observed between sucrose $50 \mathrm{~g} / \mathrm{L}$ (16.8 days) and non-sugar (16.7 days) in combination with $0.2 \mathrm{mM}$ STS in dry cold storage for one week. However, it is possible to see that the color of the lilies was different during experiment. At a concentration of $50 \mathrm{~g} / \mathrm{L}$ sucrose with $0.2 \mathrm{mM} \mathrm{STS}$, flower petals were darker in color (Figure 1). Waithaka et al. (2001) explained that pulse application of sucrose did not increase vase life or floret opening, but did overcome the deleterious effects of exogenous 
ethylene and anthocyanin content. Similarly, Han (2003) and Shiva, Chatterjee, and Bhattacharjee (2002) found that pulsing with sucrose along with STS increases the anthocyanin content, and thus the intensity of petal color. Many researchers showed that pre-treatment with sucrose and STS improves the vase life of cut flowers (Beura \& Singh, 2001; Marandi, Hassani, Abdollahi, \& Hanafi, 2011; Zhang \& Leung, 2001). They suggest that sucrose and STS act similarly on soluble sugar changes and ethylene production associated with inhibiting flower senescence and improve the maintenance of high starch concentration in the floret during flower opening. STS may improve sucrose uptake and its subsequent hydrolysis (Marandi et al., 2011). It was found that sugar delays aging (Shahri, Tahir, Islam, \& Ahmad, 2010). Sugar treatments at low concentrations cause flower buds to maintain proper form and improve the opening process. Pulsing cut carnations with STS and 10\% sucrose inhibited the ethylene synthesis and improved the postharvest quality of cut flowers (Burzo, Dobrescu, Amariujei, \& Stanica, 1995). Cut roses and chrysanthemums were pulsed with $3 \%$ sucrose, which extended the vase life by two days compared with the control (Mwangi, 2002; Song et al., 1995).

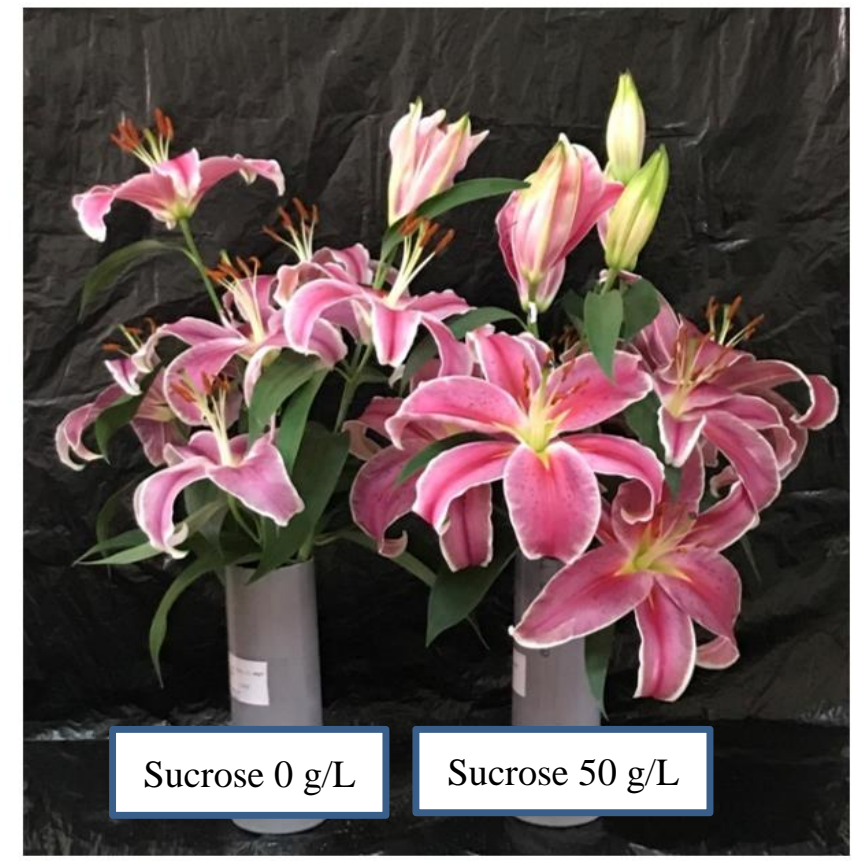

\section{Figure 1. Difference between cut lilies pulsed with water and sucrose $50 \mathrm{~g} / \mathrm{L}$ in combination with STS $0.2 \mathrm{mM}$}

The lowest vase life occurred with water pulsing (control). The flowers only lasted 14.8 and 13.6 days in dry storage for one and two weeks, respectively and 14.1 and 13.3 days in wet storage for one and two weeks, respectively. The next lowest vase life occurred with sucrose pulsing at $100 \mathrm{~g} / \mathrm{L}$ (15.3 and 14.2 days in dry storage and 14.5 days in wet storage for one and two weeks, respectively) (Table 1). Leaf yellowing was also observed in the $100 \mathrm{~g} / \mathrm{L}$ sucrose pulse treatment. This study shows that sugar treatment of lilies increases vase life, but that too much sugar can reduce vase life. Prisa et al. (2013) concluded that lily cv. Brindisi showed chilling injury when stored at $2.5^{\circ} \mathrm{C}$ and that a 
pulse treatment with sugars at $100 \mathrm{~g} / \mathrm{L}$ alleviated some of the chilling injury symptoms, but did not delay early tepal senescence and abscission, while in some experiments pulse treatments with sucrose aggravated and hastened leaf yellowing after cold storage. Many discussions about the role of sugar in solution found that sucrose pulsing had little or no effect on cold-induced hastening of tepal senescence and abscission. Vase sugar (glucose or sucrose) can increase leaf yellowing. Han (2003) found 'Stargazer' had more leaf yellowing in vase solutions containing higher concentrations of sucrose while cold storage accelerated leaf yellowing.

In this study, cold storage methods (dry and wet) were not found to affect the vase life of lilies (Table 1). This result is in agreement with the study by Cevallos and Reid (2001) who found that wet storage did not prevent the respiration-related loss of vase life during storage. Because the higher volume and weight of wet flowers will convert into higher costs of handling and transportation, this study clearly indicates that the industry should continue to transport flowers dry and minimize losses by paying closer attention to chemical pulsing and maintaining proper storage temperatures and relative humidity. Madhavi (2007) showed that pulsing treatments enhance the dry cold storage life of flowers, which can be used during export transit to overcome the delay during transport.

While dry storage and wet storage have no effect on vase life, cold storage duration has more effect on the vase life of lilies (Table 1). After one week of cold storage, non-sugar in combination with STS stored for one week extended the vase life of cut lilies by two to three days, compared to two weeks. Vase life of lilies pulsed with $50 \mathrm{~g} / \mathrm{L}$ of sucrose and STS for one week was also significantly longer by one to two days than twoweek cold storage. However, there was no significant difference between the cold storage period for treatment with water and pulsing with $100 \mathrm{~g} / \mathrm{L}$ of sucrose.

Regarding the day of bud opening, there was an interaction between sucrose pulsing and cold storage duration. It was determined that the treatment of cut lilies with a non sugar solution and STS and sugar solutions of $50 \mathrm{~g} / \mathrm{L}$ and $100 \mathrm{~g} / \mathrm{L}$ with STS for one week slowed down the time of bud opening, compared to two weeks of cold storage (Table 1). This is consistent with the study of Prisa et al. (2013) who found that bud opening during vase life was hastened by cold storage, and the more so the longer the period of cold storage. It is possible that the buds were physiologically more ready to open the longer the cold storage lasted.

An analysis of variance showed that the effects of sucrose pulsing, cold storage methods and duration on the open florets and their interaction were not statistically significant (Table 1). There was no significant difference between treatments on the rate of bud opening, both at one and two weeks of cold storage. These results confirm the findings of Han (2003) that sugar in vase pulsing does not overcome the increased bud blasting induced by cold storage, but it enables more flowers to open fully. 


\subsection{The water uptake}

While water uptake of cut lilies after three days was found to be significantly influenced by the pulsing treatments (A), cold storage methods (B) (dry and wet), and duration (C) (one and two weeks) have a significant effect on water uptake after six and nine days. Statistical analysis performed on water uptake also showed an interaction between solution pulsing and cold storage methods $\mathrm{A}^{*} \mathrm{~B}$, but no interaction between pulsing and cold storage duration $\mathrm{A} * \mathrm{C}, \mathrm{B} * \mathrm{C}$ (except after three days), and $\mathrm{A} * \mathrm{~B} * \mathrm{C}(p<0.05)$. Therefore, they were independently analysed using an ANOVA (Table 2).

Table 2. Effects of sucrose pulsing, cold storage methods, and duration on the water uptake

\begin{tabular}{|c|c|c|c|c|c|}
\hline \multirow{2}{*}{$\begin{array}{l}\text { Pulsing treatment } \\
\text { (A) }\end{array}$} & \multirow{2}{*}{$\begin{array}{l}\text { Cold storage } \\
\text { method (B) }\end{array}$} & \multirow{2}{*}{$\begin{array}{l}\text { Cold storage duration } \\
\text { (week) (C) }\end{array}$} & \multicolumn{3}{|c|}{ Water uptake (ml) } \\
\hline & & & 3 days & 6 days & 12 days \\
\hline \multirow{6}{*}{ Water } & \multirow{3}{*}{ Dry } & 1 & $45.8 \mathrm{abc}$ & $23.5 \mathrm{~cd}$ & $25.2 \mathrm{~b}$ \\
\hline & & & & & \\
\hline & & 2 & $54.3 \mathrm{ab}$ & $37.0 \mathrm{~b}$ & $24.5 \mathrm{~b}$ \\
\hline & \multirow{3}{*}{ Wet } & 1 & $48.2 \mathrm{abc}$ & $26.2 \mathrm{~cd}$ & $30.0 \mathrm{~b}$ \\
\hline & & & & & \\
\hline & & 2 & $42.7 \mathrm{bc}$ & $35.3 \mathrm{ab}$ & $31.3 \mathrm{ab}$ \\
\hline \multirow{5}{*}{$0 \mathrm{~g} / \mathrm{L}+\mathrm{STS}$} & \multirow{3}{*}{ Dry } & 1 & $40.2 \mathrm{c}$ & $21.3 \mathrm{~d}$ & $25.0 \mathrm{~b}$ \\
\hline & & & & & \\
\hline & & 2 & $51.3 \mathrm{abc}$ & $37.0 \mathrm{~b}$ & $25.5 \mathrm{~b}$ \\
\hline & \multirow{2}{*}{ Wet } & 1 & $38.3 \mathrm{c}$ & $25.2 \mathrm{~cd}$ & $28.7 \mathrm{~b}$ \\
\hline & & 2 & $39.0 \mathrm{c}$ & $38.8 \mathrm{~b}$ & $32.3 \mathrm{ab}$ \\
\hline \multirow{6}{*}{$50 \mathrm{~g} / \mathrm{L}+\mathrm{STS}$} & \multirow{3}{*}{ Dry } & 1 & $44.3 \mathrm{abc}$ & $25.0 \mathrm{~cd}$ & $22.2 \mathrm{~b}$ \\
\hline & & & & & \\
\hline & & 2 & $47.5 \mathrm{abc}$ & $32.7 \mathrm{abc}$ & $24.8 \mathrm{~b}$ \\
\hline & \multirow{3}{*}{ Wet } & 1 & $42.8 \mathrm{bc}$ & $30.5 \mathrm{abcd}$ & $32.7 \mathrm{ab}$ \\
\hline & & & & & \\
\hline & & 2 & $40.2 \mathrm{c}$ & $36.2 \mathrm{~b}$ & $33.3 \mathrm{ab}$ \\
\hline \multirow{5}{*}{$100 \mathrm{~g} / \mathrm{L}+\mathrm{STS}$} & \multirow{3}{*}{ Dry } & 1 & $49.5 \mathrm{abc}$ & $21.7 \mathrm{~d}$ & $27.5 \mathrm{~b}$ \\
\hline & & & & & \\
\hline & & 2 & $48.2 \mathrm{abc}$ & $32.0 \mathrm{abc}$ & $22.5 \mathrm{~b}$ \\
\hline & \multirow{2}{*}{ Wet } & 1 & $57.0 \mathrm{a}$ & $31.3 \mathrm{abc}$ & $35.8 \mathrm{ab}$ \\
\hline & & 2 & $56.8 \mathrm{a}$ & $48.8 \mathrm{a}$ & $44.2 \mathrm{a}$ \\
\hline
\end{tabular}

Note: Mean value has the same characters that are not significant with $p<0.050$, ns, $* *, * * *$ nonsignificance or significance at $p \leq 0.050$ or 0.001 , respectively. 
Table 2. Effects of sucrose pulsing, cold storage methods, and duration on the water uptake (cont.)

\begin{tabular}{|c|c|c|c|c|c|}
\hline \multirow{2}{*}{$\begin{array}{l}\text { Pulsing treatment } \\
\text { (A) }\end{array}$} & \multirow{2}{*}{$\begin{array}{l}\text { Cold storage } \\
\text { method (B) }\end{array}$} & \multirow{2}{*}{$\begin{array}{l}\text { Cold storage } \\
\text { duration (week) (C) }\end{array}$} & \multicolumn{3}{|c|}{ Water uptake $(\mathrm{ml})$} \\
\hline & & & 3 days & 6 days & 12 days \\
\hline A & & & $* * *$ & ns & ns \\
\hline B & & & ns & $* * *$ & $* * *$ \\
\hline $\mathrm{C}$ & & & $\mathrm{ns}$ & $* * *$ & ns \\
\hline $\mathrm{A} * \mathrm{~B}$ & & & $* * *$ & $* * *$ & $* *$ \\
\hline$A * C$ & & & ns & ns & ns \\
\hline $\mathrm{B} * \mathrm{C}$ & & & $* * *$ & ns & ns \\
\hline $\mathrm{A} * \mathrm{~B} * \mathrm{C}$ & & & ns & ns & ns \\
\hline
\end{tabular}

Note: Mean value has the same characters that are not significant with $p<0.050$, ns, **, *** nonsignificance or significance at $p \leq 0.050$ or 0.001 , respectively.

It is expected that water uptake will increase in solution pulsing compared to the water pulsing after cold storage. There was no significant differences in water uptake between solution pulsing and the control. The rates of water uptake from the $0 \mathrm{~g} / \mathrm{L}, 50 \mathrm{~g} / \mathrm{L}$, and $100 \mathrm{~g} / \mathrm{L}$ sucrose solutions and the control were $42 \mathrm{~mL}, 44 \mathrm{~mL}, 53 \mathrm{~mL}$, and $48 \mathrm{~mL}$ per stem, respectively, in the first three days (data not shown). The water uptake then decreased to $30 \mathrm{~mL}, 31 \mathrm{~mL}, 33 \mathrm{~mL}$, and $30 \mathrm{~mL}$ per stem in the next three days and finally to $27 \mathrm{~mL}, 28 \mathrm{~mL}, 33 \mathrm{~mL}$, and $28 \mathrm{~mL}$ per stem in the last three days (data not shown). Although water uptake remained unaffected by individual cold storage methods and duration, the joint application of sucrose pulsing and cold storage methods (dried and wet) had an effect on the water uptake of lilies (Table 2). The highest sucrose pulsing $(100 \mathrm{~g} / \mathrm{L})$ in wet cold storage methods had the highest water uptake from about $57 \mathrm{~mL} / \mathrm{stem}$, $31 \mathrm{~mL}$ to $48.8 \mathrm{~mL} / \mathrm{stem}$ and $35.8 \mathrm{~mL}$ to $44.2 \mathrm{~mL} / \mathrm{stem}$ after three, six, and nine days, respectively, compared to other treatments. Similar results were observed in the treatment of $50 \mathrm{~mL} / \mathrm{stem}$ and water in dry storage. The non-sugar solution with STS was significantly lower in water uptake from $38.3 \mathrm{~mL}$ to $40.2 \mathrm{~mL} / \mathrm{stem}$ in the first three days. Water uptake of cut lilies pulsed with $50 \mathrm{~g} / \mathrm{L}$ and $100 \mathrm{~g} / \mathrm{L}$ sucrose and wet cold storage increased from $25 \mathrm{~mL}$ to $48.8 \mathrm{~mL} / \mathrm{stem}$ in the next three-day (six days), compared to the non-sugar solution with or without STS.

After the last three days (nine days) in the vase solution, the water uptake did not vary significantly among treatments. Water intake was lower at nine days in all treatments, then was less from the $12^{\text {th }}$ day (data not shown). This parameter remained affected by cold storage methods, where wet storage had higher water uptake. Water uptake increases in lilies after two weeks cold storage in all treatments. This explains why the day of opening is earlier in cut lilies with two weeks of cold storage. 
Dry 1-week cold storage

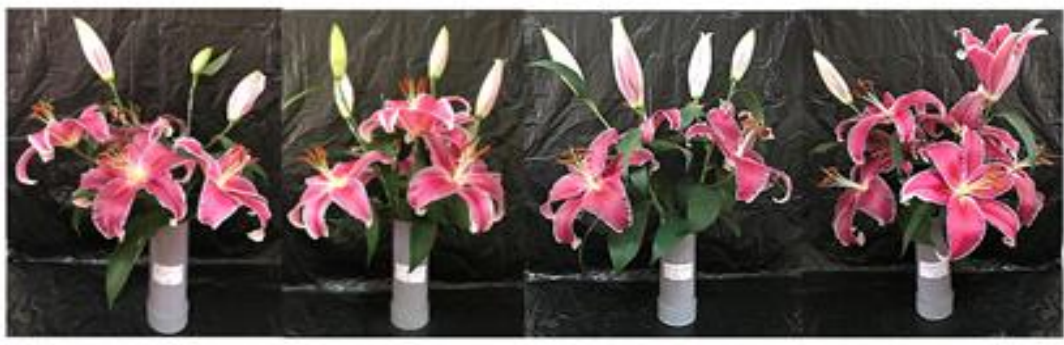

$$
\text { Water Sucrose } 0 \mathrm{~g} / 1 \quad \text { Sucrose } 50 \mathrm{~g} / 1 \quad \text { Sucrose } 100 \mathrm{~g} / 1
$$

Wet 1-week cold storage

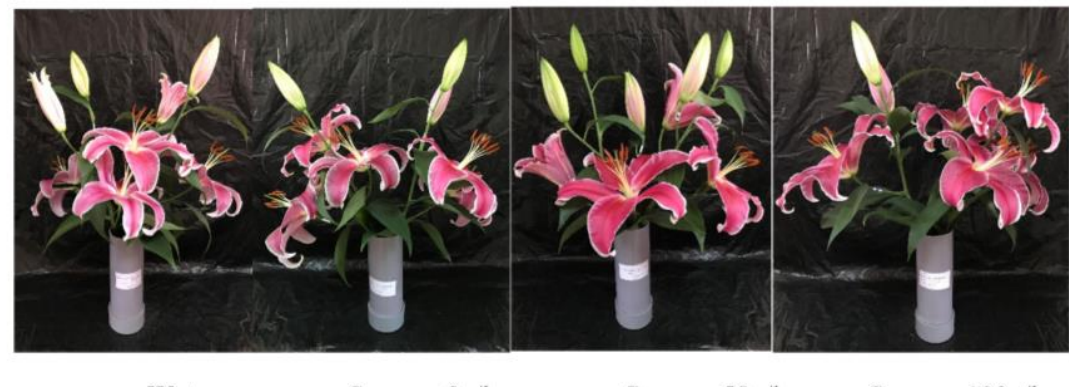
Water
Sucrose $0 \mathrm{~g} / \mathrm{l}$
Sucrose $50 \mathrm{~g} / 1$
Sucrose $100 \mathrm{~g} / 1$

Dry 2-week cold storage

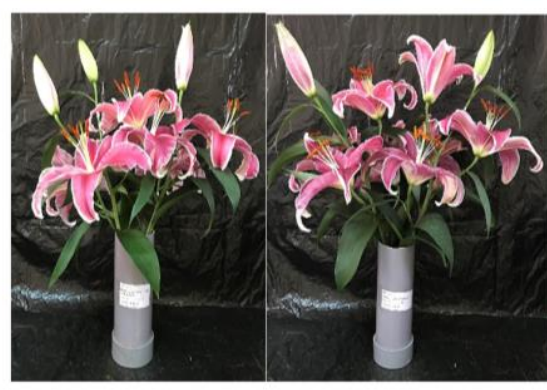

Water

Sucrose $0 \mathrm{~g} / 1$

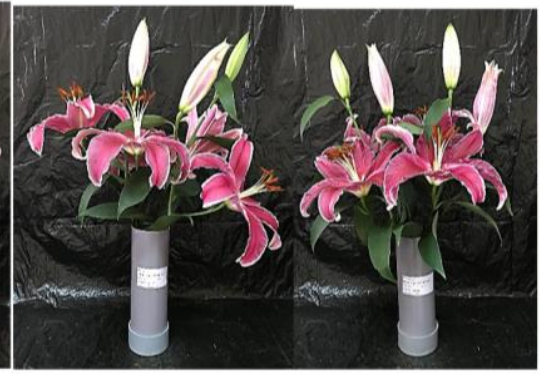

Sucrose $50 \mathrm{~g} / 1$

Sucrose 100g/l

Wet 2-week cold storage

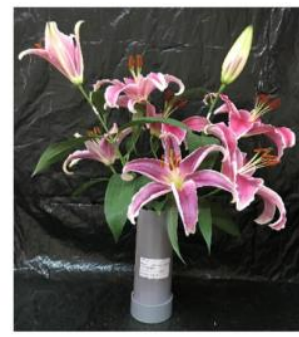

Water

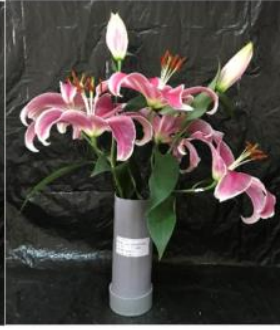

Sucrose $0 \mathrm{~g} / \mathrm{l}$

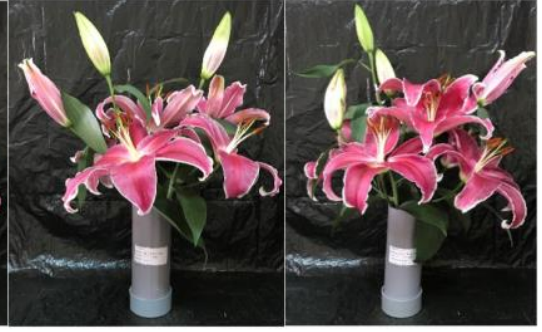

Sucrose $50 \mathrm{~g} / 1$

Sucrose $100 \mathrm{~g} / \mathrm{l}$

Figure 2. Difference between cut lilies pulsed with water and sucrose $50 \mathrm{~g} / \mathrm{L}$ and $100 \mathrm{~g} / \mathrm{L}$ in combination with STS $0.2 \mathrm{mM}$, one-week and two-week cold storage after nine days 
De la Riva, Mazuela, Alvaro, and Urrestarazu (2009) attributed the prolongation of the vase life of cut flowers by sugar application to the increase in the uptake of water by the flowers. This is in conformity with the findings of many studies on rose, gladiolus, and dendrobium hybrid flowers summarised in studies by Asrar (2012) and Pal, Lahiji, and Roy (2003). It is suggested that the increase in water uptake with sucrose treatments could be due to the increase in the osmotic concentration of the florets and leaves (de la Riva et al., 2009). The flowers were handled in water (wet storage), there was continuous water uptake by the cut rose stems, which ultimately increased the turgidity of the flowers so that they were in a continuous developmental stage. Similar results were also obtained in gerberas and carnations where the water absorption increased and fresh weight decreased with an increase in the period of dry storage (Madhavi, 2007).

Adding sucrose to the pulsing solution improves vase life and petal color (Figure 2), but does not improve the opening, rate of opening and water uptake. This study chose pulsing with sugar at $50 \mathrm{~g} / \mathrm{L}$ for the next experiment. Sugar can cause leaf yellowing, which is usually exacerbated by prior cold storage. These problems are easily reduced (with consequent improvements in flower longevity) by the use of gibberellic acid in the pulsing solution.

\section{CONCLUSION}

Both pulsing treatment and cold storage are identified as influencing the vase life of lilies, reinforcing the importance of pretreatment on lilies to improve their post-storage attributes as a means of postharvest risk mitigation. The recommended cold storage period, of up to one week in combination with a prior treatment with $50 \mathrm{~g} / \mathrm{L}$ sucrose and $0.2 \mathrm{mM}$ STS for $24 \mathrm{~h}$ for dry cold storage before placing the flower stems in water, was found to extend the vase life up to two to three days compared to other solutions and two weeks of cold storage. The data suggest that sugar is an essential component of any effective postharvest solution for the treatment of lilies. The stems pulsed with $50 \mathrm{~g} / \mathrm{L}$ of sugar in combination with STS and one week of cold storage had an average vase life two to three days longer than stems that were held in the same solution with two weeks of cold storage. Further analysis of lilies treated with gibberellic acid to delay the appearance of yellow leaves should be examined.

\section{REFERENCES}

Asrar, A. W. A. (2012). Effects of some preservative solutions on vase life and keeping quality of snapdragon (Antirrhinum majus L.) cut flowers. Journal of the Saudi Society of Agricultural Sciences, 11(1), 29-35.

Beura, S., \& Singh, R. (2001). Effect of pulsing before storage on postharvest life of gladiolus. Journal of Ornamental Horticulture, 4(2), 91-94.

Bich, L. N., \& Batt, P. J. (2011). The extent to which downstream buyers are able to fulfil flower farmers needs in Dalat, Vietnam. Paper presented at The Australian and New Zealand Marketing Academy Conference, Australia. 
Burzo, I., Dobrescu, A., Amariujei, A., \& Stanica, M. (1995). The exchange of substances between some cut flowers and solutions during vase life. Paper presented at The VI International Symposium on Postharvest Physiology of Ornamental Plants, Norway.

Cevallos, J. C., \& Reid, M. S. (2001). Effect of dry and wet storage at different temperatures on the vase life of cut flowers. HortTechnology, 11(2), 199-202.

Dang, V. D., Trinh, K. Q., Nguyen, T. H. N., Nguyen, V. T., Nguyen, T. T. T, Nguyen, X. K., \& Le, T. T. H. (2016). Selection, propagation and growing techniques of lilies in Vietnam [In Vietnamese]. Hanoi, Vietnam: Hanoi Publishing House.

de la Riva, F., Mazuela, P. C., Alvaro, J. E., \& Urrestarazu, M. (2009). Treatment with peracetic acid extends the vase life of Lisianthus (Eustoma grandiflorum) flowers. HortScience, 44(2), 418-420.

Eason, J. R. (2002). Sandersonia aurantiaca: An evaluation of postharvest pulsing solutions to maximise cut flower quality. New Zealand Journal of Crop and Horticultural Science, 30(4), 273-279.

Hajizadeh, H. S., Farokhzad, A., \& Chelan, V. (2012). Using of preservative solutions to improve postharvest life of Rosa hybrid cv. Black magic. Journal of Agricultural Technology, 8(5), 1817-1826.

Han, S. S. (2003). Role of sugar in the vase solution on postharvest flower and leaf quality of oriental lily 'Stargazer'. HortScience, 38(3), 412-416.

Ho, R. (2006). Handbook of univariate and multivariate data analysis and interpretation with SPSS. Journal of Statistical Software, 16, 1-3.

Kim, J. H., Lee, A. K., \& Suh, J. K. (2005). Effect of certain pre-treatment substances on vase life and physiological character in Lilium spp. Paper presented at The IX International Symposium on Flower Bulbs, Japan.

Madhavi, B. (2007). Studies on dry cool storage and pulsing treatments in gerbera (Gerbera jamesonii Hook.) cut flowers for export (Master's thesis). University of Agricultural Sciences, India.

Marandi, R. J., Hassani, A., Abdollahi, A., \& Hanafi, S. (2011). Improvement of the vase life of cut gladiolus flowers by essential oils, salicylic acid, and silver thiosulfate. Journal of Medicinal Plants Research, 5(20), 5039-5043.

Miller, W. (2014). Postharvest of Lilium: Experiment to Industry adaptation. Paper presented at The III International Symposium on the Genus Lilium 1027, China.

Mwangi, M. (2002). Post harvest life, quality, and biochemical constituents of cut roses as affected by precooling and storage (Doctoral dissertation). Indian Agricultural Research Institute, India.

Nemati, S. H., Tehranifar, A., Esfandiari, B., \& Rezaei, A. (2013). Improvement of vase life and postharvest factors of Lilium orientalis 'bouquet' by silver nano particles. Notulae Scientia Biologicae, 5(4), 490-493. 
Pal, R., Lahiji, M., \& Roy, S. K. (2003). Influence of storage environment, 8-HQC and sucrose on post harvest quality of 'First Red'cut rose. Journal of Ornamental Horticulture, 6(2), 130-133.

Prisa, D., Burchi, G., \& van Doorn, W. G. (2013). Effects of low temperature storage and sucrose pulsing on the vase life of Lilium cv. Brindisi inflorescences. Postharvest Biology and Technology, 79, 39-46.

Rudnicki, R. M., Nowak, J., \& Goszczynska, D. M. (1991). Cold storage and transportation conditions for cut flowers cuttings and potted plants. Paper presented at The Hortifroid, V International Symposium on Postharvest Physiology of Ornamental Plants; Importance of Cold in Ornamental, France.

Shahri, W., Tahir, I., Islam, S. T., \& Ahmad, M. (2010). Response of some ornamental flowers of family Ranunculaceae to sucrose feeding. African Journal of Plant Science, 4(9), 346-352.

Shiva, K., Chatterjee, S., \& Bhattacharjee, S. (2002). Changes in protease activity of cut roses as affected by pulsing and cold storage. Indian Journal of Horticulture, 59(2), 196-200.

Song, C., Ko, J., Shin, H., Kwon, Y., \& Lee, J. (1995). Effects of pretreatment, precooling, and shipping temperature on flower quality and vase life of cut Chrysanthemums. RDA Journal of Agricultural Science, Horticulture, 37(1), 396400.

van Doorn, W. G., \& Han, S. S. (2011). Postharvest quality of cut lily flowers. Postharvest Biology and Technology, 62(1), 1-6.

Waithaka, K., Reid, M., \& Dodge, L. (2001). Cold storage and flower keeping quality of cut tuberose (Polianthes tuberosa L.). The Journal of Horticultural Science and Biotechnology, 76(3), 271-275.

Weeraratne, T., Daundasekera, W., \& Wijesundara, D. (2012). Field survey of postharvest handling of cut flowers produced in the up country of Sri Lanka for the local market. Ceylon Journal of Science, 41(1), 67-70.

Zhang, Z., \& Leung, D. W. (2001). Elevation of soluble sugar levels by silver thiosulfate is associated with vase life improvement of cut gentian. Journal of Applied Botany, 75(3-4), 85-90. 